\title{
IMPLEMENTATION OF CONTEXTUAL TEACHING LEARNING BASED ON ISLAMIC VALUES IN MOTION SYSTEM MATERIALS TO THE LEARNING OUTCOMES AND THE SPIRITUAL INTEGRITY ATTITUDES OF STUDENTS
}

\author{
Muhibbuddin $^{1 *}$, Tania Inora ${ }^{2}$, Cut Nurmaliah ${ }^{3}$, Abdullah $^{4}$, Hasanuddin $^{5}$ \\ ${ }^{1}$ Dr, Universitas Syiah Kuala, Banda Aceh, Indonesia, muhibbuddin@unsyiah.ac.id \\ 2Universitas Syiah Kuala, Banda Aceh, Indonesia, taniainora@gmail.com \\ ${ }^{3}$ Dr., Universitas Syiah Kuala, Banda Aceh, Indonesia, cutnurmaliah@fkip.unsyiah.ac.id \\ ${ }^{4}$ Dr, Universitas Syiah Kuala, Banda Aceh, Indonesia, abdullah@unsyiah.ac.id \\ ${ }^{5} \mathrm{Dr}$, Universitas Syiah Kuala, Banda Aceh, Indonesia, hasanuddin@fkip.unsyiah.ac.id \\ ${ }^{*}$ Correspondig Author
}

\begin{abstract}
One of the impacts of Covid 19 is learning process must be carried out online. Unfortunatelly, online learning only focuses on theory and ignores the affective of students. As a consequence, it has an impact on students' affective in their daily life. One of the solutions to solve that problem is by integrated Islamic value which contained in Al- Qur'an with appropriate approach. Contextual teaching learning plays an important role in improving student's learning outcomes and it makes the students capable to integrate the motion system material with Islamic values contained in it. The method used was an experimental design with pretest - posttest non equivalent control group. The subjects were 104 students who were divided into two groups; Experimental group 1 consists of 52 students and experimental group 2 as much as 52 students. This research was conducted in the odd semester of 2020/2021 academic year at one of senior high school and Madrasah in Banda Aceh, Aceh, Indonesia. The parameters measured were learning outcomes and the attitude of students' spiritual integrity. The data of learning outcomes was analyzed through analysis of covariance, while the students' spiritual integrity was analyzed by using proportion. The results showed the application of contextual teaching learning based on Islamic value can affect learning outcomes and the attitude of students' spiritual integrity.
\end{abstract}

Keywords: CTL, Islamic value, Motion system, Learning Outcomes, Attitude of spiritual integrity.

\section{PENDAHULUAN}

One of the impacts of Covid 19 is learning process must be carried out online (Putria, 2020). Unfortunatelly, online learning only focuses on theory and ignores the affective of students. As a consequence, it has an impact on students' affective in their daily life (Widyaningrum, 2017). There are many verses of Al-qur'an that discuss the motion system. The learning process of motion system should be connected with the verses of Al- Qur'an in order to keep the learning process on the right way of Islamic path. It is related to the fact that all single things in this world have been described in Alqur'an both past, now and future. The motion system material is important to associate with the verse of Al- Qur'an, so it is useful for the students to increase their knowledge, and they can think how extraordinary god's creation is (Marazi, H. 2015).

Nanggroe Aceh Darussalam is known as the veranda of Mecca. Therefore, the culture of acehness is always integrated with Islamic values. One example of the application of Islamic law in Aceh is integrating education sector with the verse of Al- Qur'an and values contained in it. Education is the foundation of hope to develop 
individual and communities (Arif, 2019).

There are various ways to practice and implement the Al- qur'an, according to the demands of the times. One of the efforts that could be conducted by one generation to the other generation is through studying, researching, understanding and developing knowledge related to Al- Qur'an in various situations of live such as taking the values contained in Al-qur'an o be applied on the learning process of motion system (Wiguna, A. 2017).

Based on the results of interviews with biology teachers in Banda Aceh, it was obtained that the learning process of motion system only focuses on theory including anatomy and physiology of bones (Irianto, K. 2017), and it is not integrated to the values contained in the Al-Qur'an. The results of interviews with students also revealed that the motion system learning material was carried out in terms of theory through discourse and discussion methods including indicators of motion system such as structure, function and abnormalities in the motion system (Romadhon, 2017). It makes the learning process is not interesting for the students, and the process is not connected with Islamic values in Al - Qur'an.

Based on the results of observations in a school at Banda Aceh, it was gained that the learning of motion system material only discusses theory, and it is not associated with Islamic values. When teachers reprimand students, they don't pay attention to it. The interaction between students and other students was low as well as students and teachers. This has an impact on learning outcomes and the attitude of spiritual integrity of students. The score of biology test; especially in the motion system material in a school in Banda Aceh was showed that only $37 \%$ who reached the Minimum Completion Criteria (KKM) with a score of 75 . The oher students did not reach the KKM so remedials were needed (Marlina, 2020).

The learning process of motion system which relates to the verses of Al- qur'an makes science and religious teachings blended and integrated with the values in human life and has an impact on the behavior of students in learning (Yunita, 2014). If science and religious teaching are separate, learning process will be concern on theory and dispite the Islamic values implied in it. As a consequence, the behavior of students become worse (Isaac, S., 2015).

One solution to make the motion system material is easy to be understood for the students and accordance with Islamic values is through an approach that can combine the verses of the Qur'an with the material of the motion system. This approach is called as contextual teaching learning (CTL). Through CTL, the material presented by the teacher is meaningful. Students can form a relationship between knowledge and its application in life, which can affect the attitude of spiritual integrity of students (Hadiyanta, 2013).

Scientific studies on the advantages of CTL have been investigated by some researcher (O'Sullivan, 2006; Hasibuan, 2014; Jing-Wen Lin. 2016; Panjaitan, 2016). The results of this study revealed that students who took part in learning using the CTL approach have an in improvement on their learning outcomes. It is because they focused on understanding and emphasized developing students' interests and experiences in thier life. However, studies on the application of contextual teaching and learning based on Islamic values are still limited. Therefore, this research was conducted to answer the question whether the application of CTL learning based on Islamic values on the material of the motion system has an effect on the learning outcomes and the attituted of students' spiritual integrity.

\section{RESEARCH METHOD}

The research method used was an experimental, with a pretest-posttest non-equivalent control group design (Zakiyatun, 2017). The subjects of this study were 104 students who were divided into two groups: Experimental class 1 consists of 52 students and experimental class 2 consists of 52 students who were not selected randomly. This research was conducted from September-November 2020 in two secondary schools in Banda Aceh, Aceh, Indonesia. The parameters measured were the skills of learning outcomes, obtained through the pretest and posttest as many as 40 questions and the attitude of spiritual integrity of students. The data of learning outcomes were analyzed through analysis of covariance (Muhibbudin, 2020) and attitudes of spiritual integrity were tested by analyzing the percentage of questionnaire using 20 closed statements.

Tabel-1. Pretest-Postest Non-Equivalent Control Group Design

\begin{tabular}{|c|c|c|c|c|}
\hline Sample & Groups & Pretest & Treatment & Post test \\
\hline Non Randomized & Experiment 1 & $\mathrm{O}_{1}$ & $\mathrm{X}_{1}$ & $\mathrm{O}_{2}$ \\
\hline Non Randomized & Experiment 2 & $\mathrm{O}_{3}$ & $\mathrm{X}_{2}$ & $\mathrm{O}_{4}$ \\
\hline
\end{tabular}

Source: Arikunto (2002). 


\section{Information:}

$\mathrm{X}_{1}$ : Treatment 1 (CTL learning based on Islamic value)

$\mathrm{X}_{2}$ : Treatment 2 (CTL learning without Islamic value)

$\mathrm{O}_{1}$ : The pretest result of experimental group 1

$\mathrm{O}_{2}$ : The posttest result of experimental group 1

$\mathrm{O}_{3}$ : The pretest result of experimental group 2

$\mathrm{O}_{4}$ : The posttest result of experimental group 2

\section{DATA DAN ANALYSIS}

The data of students' learning outcomes were tested with analysis of covariance using a general linear univariate model. Students' spiritual integrity attitudes were tested through a percentage analysis of the questionnaire (Sugiyono. 2014).

\section{RESULT AND DISCUSSION}

\subsection{Students' Learning Outcomes}

The data of students' learning outcomes in pretest between experimental group 1 and experiment 2 are presented in Figure-1. The results of the difference mean score on pretest between the experimental 1 and experimental 2 did not show a significant difference. However, after learning (being treated through $\mathrm{CTL}$ ) the average score of posttest has a significant difference compared to the pretest score.

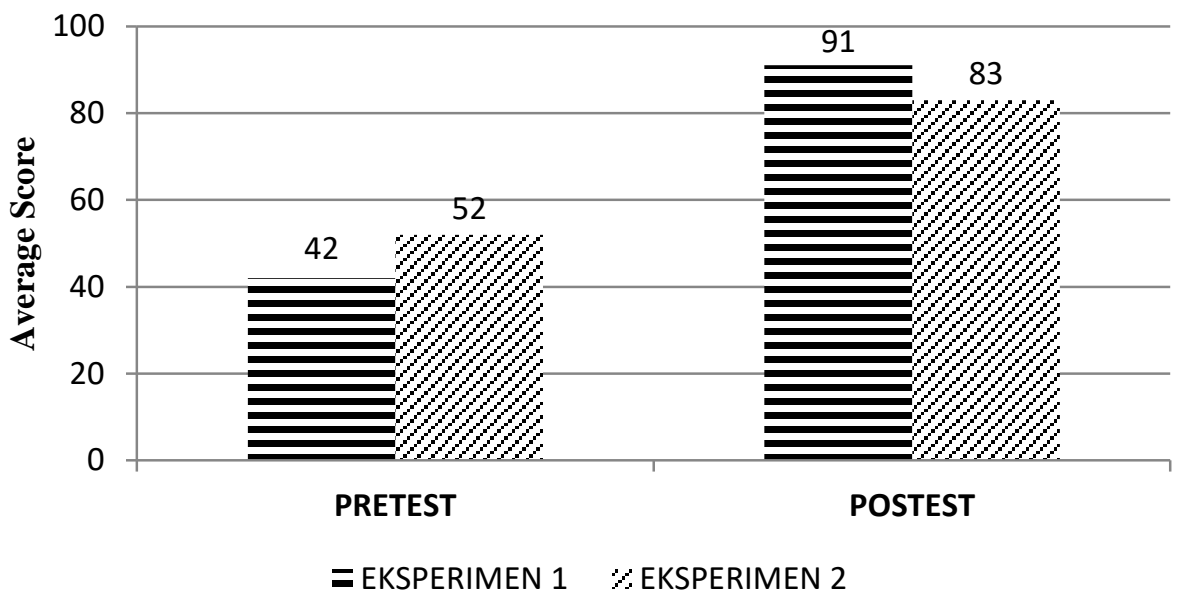

Figure-1. Average Score of pretest and posttest

Based on figure-1, it can be seen the ability of learning outcomes before being given treatment is not significantly different, the pretest has a difference of 10 points. On the other hand, the posttest score of students has a significant difference when compared to their pretest, the experimental class 1 has a difference of 49 and experiment 2 has a difference of 31.Thus it can be believed that learning CTL based on Islamic values with the material of motion system has an effect on learning outcomes of the students.

Table-2. Analysis of Covariance

\begin{tabular}{|c|c|c|c|c|c|c|}
\hline $\begin{array}{c}\text { Source of } \\
\text { Variation }\end{array}$ & $\begin{array}{c}\text { Sum of } \\
\text { Squares } \\
\text { Corrected }\end{array}$ & $\mathrm{dk}$ & $\begin{array}{c}\text { Average } \\
\text { Number of } \\
\text { Squares } \\
\text { Corrected }\end{array}$ & F-Count & $\begin{array}{c}\mathrm{F} \text {-table } \\
(0,05) \\
\mathrm{dk}=1: 65\end{array}$ & Conclusion \\
\cline { 1 - 4 } $\begin{array}{c}\text { Inter } \\
\text { Treatment }\end{array}$ & 3902829 & 1 & 3902829 & \multirow{2}{*}{12.860} & 3,92 & $\begin{array}{c}\text { Significantly } \\
\text { difference (F- } \\
\text { Count }> \\
\text { F- table }\end{array}$ \\
\hline Error-Y & 3882289 & 101 & 38061 & & & \\
\hline Total & 7785118 & 102 & & & \\
\hline
\end{tabular}


The results of analysis of covariance in Table-2 shows that the F-count> F-Table. It can be concluded the results are significantly different or there is significant differences between the treatments; Experimental group taught with CTL based on Islamic values and experimental 2 taught using non Islamic CTL. It is indicate the application of CTL approach to the motion system material based on Islamic values can affect students' learning outcomes.

\subsection{The Attitude of Student's Spiritual Integrity}

The integrity of students in learning can be seen after the distribution of questionnaires filled out by each student after the learning activity takes place. Based on the results of the data on the integrity attitudes of students in the experimental class 1 and experiment 2, it shows that there are differences in the responses of students, although it was not significantly from the three indicators. Students' response data can be seen in Table-4.

Table - 4. The Attitude of Students' Spritiual Integrity

\begin{tabular}{|c|c|l|c|c|c|c|}
\hline \multirow{2}{*}{ No. } & \multirow{2}{*}{ Variable } & \multicolumn{1}{|c|}{ Indicator } & \multicolumn{4}{c|}{ Students' Response } \\
\cline { 3 - 7 } 1. & Bones & $\begin{array}{l}\text { Students are able to examine } \\
\text { Islamic values in the human } \\
\text { bones }\end{array}$ & 84 & $\begin{array}{l}\text { Very } \\
\text { Good }\end{array}$ & 71 & Good \\
\hline 2. & Muscle & $\begin{array}{l}\text { Students are able to examine } \\
\text { the Islamic value in muscles }\end{array}$ & 79 & Good & 75 & Good \\
\hline 3. & Joint & $\begin{array}{l}\text { Students are able to study } \\
\text { Islamic values in joints }\end{array}$ & 83 & $\begin{array}{c}\text { Very } \\
\text { Good }\end{array}$ & 79 & Good \\
\hline \multicolumn{2}{r}{} & Total & 82 & $\begin{array}{c}\text { Very } \\
\text { Good }\end{array}$ & 75 & Good \\
\hline
\end{tabular}

Based on Table-4, it is known the attitude of students' integrity in the experimental class 1 was in very good category with a percentage of $82 \%$, while in the experimental class 2 the data was in the good category with a percentage of $75 \%$. The comparison of the spiritual integrity attitudes of students in the experimental class 1 and the experimental class 2 can be seen in Figure- 2 .

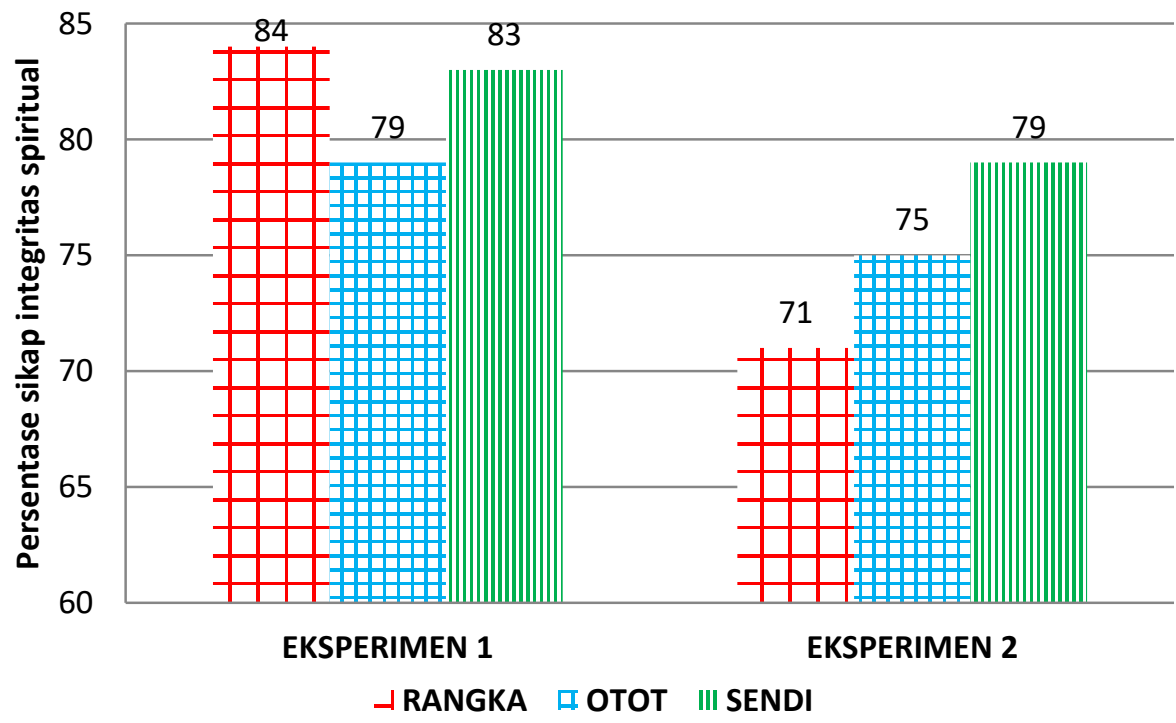

Figure-2. Picture of Spiritual Integrity Attitude Percentage

Based on Figure-2, it is known there is a difference between the experimental class 1 and 2 although it was not very significant. Three indicators of spiritusal integrity attitude towards learning motion systems based on Islamic values include bones, muscles and joints. The percentage score of the spiritual integrity attitude of students in the experimental class 1 is higher than the score for the experimental class 2 , this is due to the advantages of the CTL approach.

CTL learning based on Islamic values in motion system material can affect the integrity attitude of students in combining science with Islamic values contained in it. This data analysis is in line with research conducted by 
(Arif, 2019) entitled "Integration of Islamic Values in Learning" which states the application of an attitude of integrity has a very good effect on combining science and Islam which has an impact on the integrity attitude of students, especially in the modern era who made a separation between Islam and all aspects of world life or what is known as secularism which has taken root in various aspects of life including in educational institutions.

\section{CONCLUSION}

Based on the results of the study, it shows that learning through contextual teaching learning approach based on Islamic value has an effect on learning outcomes and attitudes of students' spiritual integrity.

\section{REFERENCE LIST}

Arif, M. Z. (2019). Integration of Islamic Values in Learning. Jurnal Pendidikan Islam. 4(2): 132-143.

Arikunto, S. (2002). Pengembangan Instrumen Penelitian dan Penilaian Program. Yogyakarta: Pustaka Pelajar.

Crick, R. D; and Jelfs, H. (2011) Learning and Personalisation: Exploring the Relationship between Spiritual Development and Learning to Learn in a Faith-Based Secondary School International. Journal of Children's Spirituality. 16(3).

Hadiyanta, N. (2013). Penerapan Model Pembelajaran Contextual Teaching And Learning (CTL) Untuk Meningkatkan Hasil Belajar PKN. Jurnal Kependidikan. 43(1).

Hasibuan, I. (2014). “Model Pembelajaran CTL (Contextual Teaching And Learning). Jurnal Logaritma. 2(1): 1-12.

Ishak, S. (2015). Metode Pembelajaran Sains. Dalam Perspektif Pendidikan Islam. Jurnal IImiah Islam Futura. 15(1). 143-161.

Irianto, K. (2017). Anatomi dan Fisiologi. Bandung: Alfabeta.

Jing-Wen Lin. (2016). “Examining the Factors That Influence Students' Science Learning Processes and Their Learning Outcomes: 30 Years of Conceptual Change Research". Eurasia Journal of Mathematics, Science \& Technology Education. 12(9): 2617-2646.

Kenedi, A. K. (2018). Pengembangan Bahan Ajar Matematika Berbasis Al-Qur'am Di Sekolah Dasar. Jurnal Inovasi Pendidikan dan Pembelajaran Sekolah Dasar. 2(1): 29-36.

Marazi, H. (2015). Empowering Education With Values and Integration Of Religion and Science: Madrasah Al-Zahra Model. Proceedings of International Conference on Empowering Islamic Civilization.

Muhibbudin. (2020). Analisis Kovarian. Darussalam: Universitas Syiah Kuala

Mulyasa. (2013). Pengembangan dan Implementasi Kurikulum 2013. Bandung: Remaja Rosdakarya.

Panjaitan, D. J. (2016). Penerapan Pendekatan Contextual Teaching And Learning (CTL) Untuk Meningkatkan Hasil Belajar Statiska. 1(1): 1-10.

Putria,H; Maula,L.H; dan Uswatun, D.A. (2020). Analisis Proses Pembelajaran dalam Jaringan (DARING) Masa Pandemi Covid- 19 Pada Guru Sekolah Dasar. Jurnal Mudarrisuna. 4(4). 131-147.

Romadhon, E. N; Anra, H; \& Pratiwi. (2017). Penerapan Augmented Reality

Berbasis Android Sebagai Media Pembelajaran Sel Penyusun Jaringan pada Sistem Gerak dalam Mata Pelajaran Biologi. Jurnal Sistem dan Teknologi Informasi. 5(2): 89-92.

Sugiyono. (2014). Metode Penelitian Pendidikan Pendekatan Kuantitatif, Kualitatif, dan R\&D. Bandung: Alfabeta.

Widyaningrum, D.A; Dan Wijayanti, T. (2017). Pemberdayaan Hasil Belajar Afektif Mahasiswa Melalui Model Pembelajaran Search, Solve, Create, And Share (Sscs) Berbantuan Media Video. Jurnal Penelitian Pendidikan Biologi. 1 (2), 105-112. 
Wiguna, A. (2017). Upaya Mengembangkan Sikap Spiritual Dan Sosial Peserta

Didik Berbasis Psikologi Positif Di Sekolah. Journal Of Basic Education. 1(2): 47-61.

Yunita, I.E; \& Hakim, L. (2014). Pengembangan Modul Berbasis Pembelajaran

Kontekstual Bermuatan Karakter. Jurnal Pendidikan Akuntansi. 2(1): 1-6.

Zakiyatun, C; Cawang; Dan Kurniawan, R.A. (2017). Pengaruh Media Peta Konsep Dalam Model Pembelajaran Kooperatif Tipe Numbered Heads Together (Nht) Terhadap Hasil Belajar Dan Daya Ingat Siswa Pada Materi Hidrolisis Garam Kelas Xi Mipa Sma Negeri 7 Pontianak. Ar-Razi Jurnal IImiah. 5(2). 159-168. 